\title{
Adjuvant chemotherapy for resected non-small- cell lung cancer: future perspectives for clinical research
}

\author{
Maria Bonomi ${ }^{1}$, Sara Pilotto ${ }^{1}$, Michele Milella ${ }^{2}$, Francesco Massari ${ }^{1}$, Sara Cingarlini ${ }^{1}$, Matteo Brunelli ${ }^{3}$, Marco Chilosi $^{3}$, \\ Giampaolo Tortora ${ }^{1}$ and Emilio Bria ${ }^{1 *}$
}

\begin{abstract}
Adjuvant chemotherapy for non-small-cell lung carcinoma (NSCLC) is a debated issue in clinical oncology. Although it is considered a standard for resected stage II-IIIA patients according to the available guidelines, many questions are still open. Among them, it should be acknowledged that the treatment for stage IB disease has shown so far a limited (if sizable) efficacy, the role of modern radiotherapies requires to be evaluated in large prospective randomized trials and the relative impact of age and comorbidities should be weighted to assess the reliability of the trials' evidences in the context of the everyday-practice. In addition, a conclusive evidence of the best partner for cisplatin is currently awaited as well as a deeper investigation of the fading effect of chemotherapy over time. The limited survival benefit since first studies were published and the lack of reliable prognostic and predictive factors beyond pathological stage, strongly call for the identification of bio-molecular markers and classifiers to identify which patients should be treated and which drugs should be used. Given the disappointing results of targeted therapy in this setting have obscured the initial promising perspectives, a biomarker-selection approach may represent the basis of future trials exploring adjuvant treatment for resected NSCLC.
\end{abstract}

Keywords: adjuvant chemotherapy, early stage lung cancer, stage Ib, prognostic predictive classifiers

\section{Background}

Adjuvant chemotherapy (ACT) for NSCLC still represents a major topic in clinical oncology. According to guidelines from the European Society of Medical Oncology (ESMO) [1], American Society of Clinical Oncology (ASCO) [2], National Comprehensive Cancer Network (NCCN) [3] and American College of Chest Physicians (ACCP) $[4,5]$ cisplatinum based ACT is now considered a standard treatment for resected stage II-IIIA with an estimated survival benefit of $4-5 \%$ at 5 years. Nevertheless, many issues such as the management of stage IB, the role of postoperative radiotherapy (PORT), the treatment of elderly-unfit patients, the best regimen and schedule to be used and the long term effects of ACT, are still under investigation. Moreover, the narrow ACT

\footnotetext{
* Correspondence: emiliobria@yahoo.it

'Medical Oncology, Azienda Ospedaliera Universitaria Integrata (AOUI), Verona, Italy

Full list of author information is available at the end of the article
}

therapeutic index (i.e. limited survival benefit with considerable toxicity) requires a careful assessment of expected risks and benefits for each patient.

To date, no other prognostic or predictive factors beyond pathological stage have been prospectively validated. Molecular markers or classifiers could better identify which patients should be treated with, or spared by, chemotherapy and which drugs should be better used (assuming a differential sensitivity to a particular agent/regimen). Despite researchers' efforts, this still represents an unmet medical need. The purpose of this review is to summarize the available evidences on ACT in the context of the new recent advances in the field of translational and bio-molecular research.

\section{The historical perspective: so far, so good?}

Since the NSCLC Collaborative Group landmark metaanalysis, which first indicated a small benefit in favor of

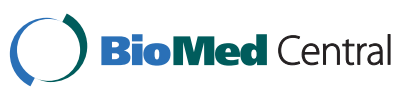


ACT for resected NSCLC [6], many randomized clinical trials have been released with conflicting results.

The Adjuvant Navelbine International trial association (ANITA) trial [7] and the National Cancer Institute of Canada Clinical Trial Group (NCIC CTG) JBR-10 trial [8] confirmed the OS benefit of Cisplatinum and Vinorelbine adjuvant chemotherapy. The former enrolled stage I-IIIA patients and allowed the use of PORT, while the latter was limited to IB-II without radiotherapy. The OS improvement was $8.6 \%$ and $15 \%$ at 5 years, with HR of 0.79 and 0.7 respectively, maintained at longer follow up $[7,9]$. The International adjuvant lung cancer trial (IALT) [10], despite positive results at first analysis (4\% reduction in the risk of death in enrolled stage II-IIIA patients undergoing platinum based ACT with either etoposide or vinca alkaloids [11]), failed to maintain the same benefit with longer follow up. So did the "stage IB-focused" CALBG 9633, which used a carboplatinum based regimen $[12,13]$. The negative results of the Big Lung Trial (BLT) [14], the Adjuvant Lung Project Italy (ALPI) [15] and ECOG 3590 [16] further jeopardized evidence on ACT.

The description of each trial is beyond our aim, however differences in study design, patient selection, schedule/regimen administered, and use of PORT could partially explain the conflicting outcomes [17].

In 2008 the LACE meta-analysis pooled individual patients' data from 5 of these trials $[7,8,10,14,15]$ (using modern platinum based - ACT and conducted after 1995 ; 4584 patients) and showed a statistically significant absolute OS benefit of $5.4 \%$ (HR for death $=0.89$; 95\% CI 0.82-0.96; $\mathrm{p}=.005$ ) [18].

The results of other meta-analysis [19-22] showed similar HR/RR for death for platinum based -ACT (0.86 -0.93), regardless of the method used (individual patients' data vs abstracted data). So did the recent update of the NSCLC-meta-analysis Collaborative Group (HR 0.89. 95\% CI 0.82-0.97, p = 0.006 HR 0.86. 95\% CI 0.81-0.92, p <.0001, absolute OS benefit: $4 \%$ at 5 years for the overall population)[23]. In a larger setting, community based surveys or multinstitutional database analyses show an increasing employment of ACT (with a consequent survival improvement) [24-29]. These data, interpreted with the caution requested by their retrospective and not randomized fashion, suggest that the benefit may also be extended into the context of patients treated in routine clinical practice.

With the aim to better interpret the quantitative and qualitative differences among randomized clinical trials results, IALT, JBR-10 and ANITA were analyzed with a bayesian approach, weighting the results on the basis of continuously updated outcome hypotheses [30]. Nevertheless, the $13 \%$ relative death risk reduction corresponding to an absolute 4-5\% survival benefit did not increase overtime when considering the former NSCLC Collaborative Group meta-analysis publication [6] and its recent update [23]. These small benefit strongly call for an optimization of the therapeutic index of adjuvant treatment.

\section{The stage IB dilemma: Does (just) the size matters?}

The management of stage IB (according to the 6th TNM edition) is still controversial. To date, evidence show that benefit from adjuvant chemotherapy for stage IB, if any, is small: 43 IB patients should be treated for one to benefit (number needed to treat, NNT), nearly 3 times the 15 NNT for stage II-IIA [2]. In addition, available results come from a trial with limited sample size (CALGB 9633) and from subgroup analysis of other randomized trials (with few enrolled stage IB patients), both underpowered to detect the small differences expected in OS.

In this regard, both the CALBG 9633, specifically designed for stage IB disease, and subgroup analyses of the IALT, JBR-10 and ANITA $[7,8,11]$ trials failed to demonstrate any survival benefit [13]. A possible beneficial effect was seen for tumors larger than $4 \mathrm{~cm}$ (in comparison with smaller tumors) in CALBG 9633 (HR $0.69 ; \mathrm{p}=.043$ vs $\mathrm{HR}=1.12 ; \mathrm{p}=.32$ ) [13] and JBR-10 (HR 0.66 vs 1.73) [8]. Since both these analyses were post-hoc, results are not conclusive, given also that the benefit lowers overtime [31]. Similarly, in LACE metaanalysis stage IB only trended toward an OS benefit. The HR was 0.93 (95\% CI $0.78-1.10)$, against 0.83 and 1.14 for stage II-III and IA, respectively [18].

The subgroup analysis from the NSCLC CG metaanalysis update according to stage [23] and limited to platinum-based regimens, showed an identical 5 years OS improvement of $5 \%$ for stage IB (from 55 to $60 \%$ ), stage II (from 40 to $45 \%$ ) and stage III (from 30 to $35 \%$ ), with a non significant test for trend $(\mathrm{p}=0.13)$ [23].

A $11 \% 5$ years survival gain (from $74 \%$ to $85 \%$ ) was observed in Japanese patients with resected stage Ib adenocarcinoma treated for 2 years with oral Uracil-Tegafur. Although promising, these results cannot be directly extendend to Western countries whereas Uracil-Tegafur has not been reliably tested so far [32].

Conducting prospective trials restricted (and powered) for stage IB patients would be the only way to unravel this issue. However, the prohibitively large sample size required undermines the feasibility of such an approach [33].

In addition, other (molecular) prognostic factors are needed to identify among these borderline patients, those at higher risk. Nonetheless, the worse prognosis observed with increasing $\mathrm{T}$ size has been recognized in 
the VII TNM edition. T2 was divided into T2a $(3-5 \mathrm{~cm})$ and T2b $(5-7 \mathrm{~cm})$, with a OS of 58 and $49 \%$ at 5 years, respectively $(\mathrm{p}<.0001)$ [34]; T2bN0 was upstaged to stage IIA [35]. Correlation with the new staging system failed to validate the $5 \mathrm{~cm}$ cut-off in the 9-years update of CALGB 9633, showing a trend towards a significant benefit for adjuvant treatment for patients with tumors $>7 \mathrm{~cm}[\mathrm{HR}=0.53 ; \mathrm{p}=.051]$ [31], although interaction should be investigated.

Recent studies investigated further pathological prognostic factors for resected VII edition-stage IB (T2aN0), such as the presence of microscopic vascular invasion [36] or intratumoral vascular and/or visceral pleural invasion [37]. Although promising, these results require a prospective external validation.

Finally, the question of 'which stage IB deserves adjuvant treatment' remains still unanswered. Size may represent a selection criterion, while awaiting for more powerful pathological and biological predictors.

\section{Post Operative Radiotherapy (PORT): has the 1998 sentence expired?}

Few and underpowered randomized clinical trials exploring the role of PORT in patients after resection of NSCLC have been conducted from the early 90s, with inconclusive results. In order to look for a small survival benefit, the individual patients' data PORT meta-analysis (initially including 9 randomized clinical trials) was performed [38]. The last update (11 trials, 2343 patients) showed a statistically significant detrimental effect on OS for patients receiving PORT $(\mathrm{HR}=$ 1.18; 95\% CI 1.07-1.31; $\mathrm{p}=.0001 ; 5 \%$ 2-years absolute difference). Similar conclusions were reached for local and distant Recurrence-Free Survival (RFS) $(H R=1.12$, $\mathrm{p}=.03$ and $\mathrm{HR}=1.13, \mathrm{p}=.02$, respectively). A highly significant interaction according to stage and nodal status was detected, indicating a substantial absence of PORT effect in stage III or N2 patients (HR 0.99 and 0.97), restricting the detrimental difference to lower stage disease [39].

Abandoned techniques, such as Cobalt-60, large irradiation fields (including the entire mediastinum), different total doses (30-60 Gy), unconventional daily fractions (up to 2,6-3 Gy) represent some of the limitations of the trials included in the PORT meta-analysis, thus undermining its validity in a modern setting. One of the hypotheses is that the excess in non cancer related deaths, mainly due to cardiovascular and lung toxicity, could have outweighed the potential small benefit on local recurrence [40].

The effect of PORT was also assessed in an unplanned analysis of the ANITA trial. Although no formal statistical comparison could be made between subgroups, a positive effect of PORT was suggested for N1 patients in the control arm and for N2 patients overall [41]. The latter derived the largest benefit from the association of adjuvant chemotherapy plus PORT, followed by chemotherapy alone, PORT alone and observation (5-years OS: $47.4 \%, 34 \%, 21.3 \%, 16.6 \%$, respectively) [7]. Although retrospectively derived on a relatively small sample size, these results provide intriguing data on the effect of modern PORT after optimal adjuvant chemotherapy.

Data from more recent series (although retrospective or community-based) showed a decreasing treatment related death rate with modern techniques such as 3dimensional (3D) or imaging guided (IMRT) to minimize irradiation of normal tissues (heart and lungs) and maximize the optimal delivery to the targeted fields [42]. A better selection of patients (i.e. only those with extended mediastinal involvement [43] or at higher risk of relapse [44]) may potentially increase the PORT therapeutic index.

Although large, well-designed, prospectively trials evaluating the efficacy of modern PORT are required, the CALGB 9734 prematurely closed due to slow accrual. The Lung Adjuvant Radiotherapy Trial (Lung ARTNCT00410383) comparing 3D-conformal PORT with no PORT in resected N2 patients after the delivery of any planned (neo)-adjuvant chemotherapy is currently ongoing.

\section{Treatment efficacy according to age}

Older age and comorbidities may profoundly affect treatment tolerability and overall mortality rate. Few trials have been specifically conducted in elderly (and frail) patients; thus, the vast majority of data derive from retrospective analyses of randomized clinical trials designed for an adult population.

In the subgroup analysis from the JBR-10, no differential effect favoring adjuvant chemotherapy according to age (cut-off 65-years) was found; indeed, in the 155 patients over $65-\mathrm{s}$, the HR for death still favored adjuvant treatment $(0.61 ; 95 \%$ CI $0.38-0.98 ; \mathrm{p}=.04)$, in spite of the smaller cumulative doses of cisplatin and vinorelbine [45].

The update of the LCCG meta-analysis did not show differential effect of adjuvant chemotherapy according to age [23], as well as the LACE pooled analysis. In addition, no difference in severe toxicity were encountered according to age (lower cumulative doses?)[46].

A recently published practice-based survey from SEER registry showed that platinum based ACT administered outside of clinical trials to unselected elderly patients was associated with a significant survival benefit (although limited to those under 80-years and associated with a higher risk of serious adverse events)[28]. Moreover, the data from the Cancer Ontario Registry 
confirmed, once again, the benefit of ACT in the elderly populations (even if any apparent increased toxicity was observed)[26].

The LCCG meta-analysis did show a significant trend $(p=0.002)$ against the adoption of adjuvant chemotherapy in patients with a worsening performance status (PS) [23] In this regard, LACE subgroup analysis showed increasing benefits from adjuvant chemotherapy with better PS ( 0 vs 1 ), with a detrimental effect for PS 2 (test for trend $\mathrm{p}=.009$ for OS) [18].

These results suggest no differential effect of adjuvant chemotherapy when age is the only variable [47], at least when interpreting data from the available randomized clinical trials; whether the daily elderly patient might derive the same benefit from adjuvant chemotherapy should be weighted in the context of comorbidities and other prognostic factors.

\section{Cisplatinum-based chemotherapy: is there a 'winning' doublet?}

Clear and definitive evidence with regard to which would be the best partner to be associated with adjuvant cisplatinum is still awaited. The current opinion, generally shared by ASCO, NCCN, ACCP, and ESMO, is that any cisplatinum-combination (according to the approved dose and schedules for advanced setting) may be administered to patients who have undergone radical resection and who are (at least apparently) disease-free after surgery [1-5]. In addition, doses and schedules should be tailored according to the patients' compliance and the physicians' attitude ("practitioners adopt one cisplatin-based chemotherapy regimen to use consistently to ensure familiarity and optimize patient safety") [2]. This 'opened-minded' instead of 'rigorous' interpretation of available scientific evidence represents a matter of discussion, although it should be recognized that clear recommendations with modern regimens for the daily practice are lacking and are still far to be produced.

With regard to the available evidences to date, the combination cisplatinum plus vinorelbine should be considered to have a 'groundless supremacy'. Indeed, in the prospectively planned subgroup analysis from LACE, cisplatinum and vinorelbine trended toward a major benefit $(\mathrm{HR}=0.80 ; 95 \% \mathrm{CI} .=0.7-0.91 ; \mathrm{p}<.001)$ if compared to other regimens (interaction test $\mathrm{p}=$ .004) [18], and this benefit was stage dependent (interaction $\mathrm{p}=.02$ ).

Currently, two issues should be considered: a) patients receiving $>300 \mathrm{mg} / \mathrm{m} 2$ of cisplatinum performed better than those receiving $<300 \mathrm{mg} / \mathrm{m} 2$. This featured patient subgroup overlaps for almost $65 \%$ with that of patients receiving vinorelbine, in comparison with half of those receiving other regimens. Whether the benefit of cisplatinum and vinorelbine depends on the combination of the 2 drugs or from higher cisplatinum dose cannot be easy established [18]; b) the planned schedule of cisplatinum was $50 \mathrm{mg} / \mathrm{m} 2$ day 1 and 8 in JBR10 and $100 \mathrm{mg} /$ $\mathrm{m} 2$ day 1 in ANITA; vinorelbine in both trials was meant to be delivered $25-30 \mathrm{mg} / \mathrm{m} 2$ weekly for 4 cycles (16 doses). In JBR10 the actual dose was $84 \%$ and 52\% for cisplatinum and vinorelbine respectively, with higher toxicities occurring in older, female and after pneumonectomy [48]. In ANITA only $50 \%$ of patients completed the planned 4 cycles.

\section{The 'fading effect' of chemotherapy}

According to the breast or colon cancer models, the benefit of adjuvant treatment may vary over time; the data from NSCLC are conflicting. Long term effect of platinum based ACT was maintained in ANITA after 5 years and in the 7-years (projected) analysis (OS benefit of $8.6 \%$ and $8.4 \%$, respectively)[7] and in JBR10 (absolute OS benefit of $11 \%$, after 9.3 years and $12 \%$ at 5 years) [9]. However the updated results of CALBG 9633 [13] and IALT [11] did rise many concerns.

CALBG 9633 first analysis (at 2.8 years) showed a promising $11 \%$ OS increase in stage IB, which lead to early stopping of the study [12]. Unfortunately this was no longer confirmed after the 4.5 [49] and 6 years updates [13]. In the IALT trial (the largest with 1867 patients), the OS benefit after the 90 months analysis was less evident (and not statistically significant anymore) in comparison with the analysis performed at 56 months (HR 0.91 and 0.56 , respectively). The rate of non-lung cancer related deaths increased by $20 \%$, as compared with the first interim analysis, mostly after 5 years of follow up [11]. Although the unbalanced population taken into account after the 5-years time-point should to be considered as a randomized comparison, long term side effects of citotoxic drugs and the high rate of comorbidities in NSCLC patients may partially explain these results [50]. However some differences in classification and reporting of death causes may have influenced the reported outcomes [17].

LACE data show a sustained effect of ACT over time (survival gain of $3,9 \%$ and $5,4 \%$ at 3 and 5 years, respectively). Considering only lung cancer-related deaths, the benefit was even higher $(+6,9 \%$ at 5 years), partially outweighed by the higher rate of non lung cancerrelated deaths observed in the ACT group.

\section{The integration of bio-molecular predictors in the risk assessment process: are they ready for prime time?}

An effective risk assessment is essential to identify "high-risk" stage IB (IA?) patients benefiting from ACT and spare some "low-risk" stage II from the toxicities of a treatment not impacting on their OS. Which factors should be considered in this clinical decision process? 


\section{Clinico-pathological factors}

Pathological stage is the only prospectively validated prognostic factor to guide the prescription of adjuvant chemotherapy, although based on inadequate prognostic power to stratify patients within the same TNM category [51,52]. Older age, male gender, poorer PS and non-squamous cell histology are currently known to be associated with decreased survival, although their additional weight to clinical staging does not increase its prognostic power [53].

We previously investigated the independent prognostic role of the number of resected nodes and of the ratio between metastatic and resected nodes. The generated prognostic model was able to powerfully stratify patients into 3 classes [54]. Recently, a large retrospective analysis from the SEER database showed that the increasing number of resected positive nodes and a higher ratio between metastatic and overall resected nodes have an independent negative prognostic impact for overall survival in N1 patients $[55,56]$. Although a prospective validation is mandatory, these results suggest the inclusion in the next TNM of other nodal descriptors than site and status to improve the prognostic power.

\section{Molecular factors}

Several molecular prognostic (and predictive) models have been published in the attempt to improve the clinical decision process [57-62]. Although promising, their effectiveness and clinical utility were undermined by several limitations: the inability to account for comorbidities and other clinical factors (which affect prognosis) [63], methodological and statistical biases, lack of a solid and reproducible internal and external validation $[64,65]$.

The proposal of a new prognostic model should always be supported by reliable validations. A pivotal example is represented by the recent retraction by Potti et al of their promising metagene expression model (which led to stop the CALBG 30506 trial and to remove the metagene analysis from the study design) [66].

The analysis of the data from the available randomized trials exploring the role of eventual predictors for either prognosis or treatment efficacy hides many drawbacks given its retrospective nature. This is further complicated by the extremely relevant impact of the attrition rate for the analysis of biological samples [67]. Nevertheless, many investigators involved in those trials exploring the benefit of adjuvant chemotherapy planned and conducted intriguing analyses to generate working hypotheses for future biomarker-driven randomized trials, as follows:

- IALT-BIO: the low IHC expression of the excision repair cross complementation group 1 (ERCC1) represents a marker of better outcome in patients receiving cisplatinum in $\mathrm{ACT}(\mathrm{HR}=0.65 ; \mathrm{p}=.0002$ vs $\mathrm{HR}=1.14 ; \mathrm{p}=.4$ for high expression; interaction test $\mathrm{p}=.0009)$; conversely, high ERCC1 expression correlates with longer OS in the control group (HR $=0.66$ ) [68]. In the context of cell cycle regulators, $\mathrm{p} 27$, while having a predictive role for patients treated with ACT, does not affect prognosis (p27 negative HR 0.66; $\mathrm{p}=.006 ; \mathrm{p} 27$ positive HR 1.09; $\mathrm{p}=$ .54 ; interaction test $\mathrm{p}=.02)[69]$. Similarly to ERCC1, the low expression of MutS homologue 2 (MSH2) was predictive of benefit from platinum based -ACT (low MSH2 HR $=0.76 ; \mathrm{p}=.03$ vs high MSH $2 \mathrm{HR}$ $=1.12 ; \mathrm{p}=.48$; interaction test $\mathrm{p}=.06)$. MSH2 high expression was also prognostic for longer survival in untreated patients $(H R=0.66 ; p=.01)[70]$. In order to test the prognostic power of the combination of these 3 markers, patients were clustered into 4 categories according to low/high level of MSH2/ERCC1: the benefit from ACT decreased with the increasing number of positive markers (HR for low ERCC/low MSH 20.65; $p=.01$ ). Similar results were shown for p27/ERCC1. Nevertheless, the prognostic effect decreased over time [70]. The other analyzed markers had a weaker or null predictive role $[71,72]$.

- JBR-10-[BIO]: K-RAS wt and p-53 wt patients seemed to benefit more from ACT with cisplatinum and vinorelbine (vs mutants) although the interaction test for treatment effect was not significant. P53 expression was prognostic of worse OS in the control arm $(\mathrm{HR}=1.89 ; \mathrm{p}=.03)$, while in the treatment arm it had a positive predictive role $(\mathrm{HR}=0.54 ; \mathrm{p}=$ .02)[73]. From JBR-10 dataset an m-RNA based-15 gene signature was proposed to differentiate high from low risk patients. The HR for death in the observation group was 18 (adjusted at multivariate analysis; 95\% CI 5.12-44.04; $\mathrm{p}<.001$ ). The prognostic power was validated on 4 separate dataset and by RT-PCR on the original dataset. The positive predictive role was confirmed for high risk group (HR of death 0.33 ; 95\% CI 0.17-0.63; $\mathrm{p}=.0005$ ) but not for low risk $(\mathrm{HR}=3.67 ; \mathrm{p}=.21)$. The external, prospective validation is awaited to confirm these results [74]. Although unpowered to assess the prognostic or predictive impact of EGFR mutation and copy number, a possible trend toward a positive predictive role of the mutation (and copy number) was proposed in JBR10.

- LACE BIO (ANITA, JBR10, IALT and CALBG 9633): High class III beta tubulin (TUBB3) expression maintained the negative prognostic impact seen in previous analysis (HR for death $=1.3 ; \mathrm{p}=.001$ ). In metastatic setting, high TUBB3 expression caused resistance to tubulin-targeting agents [75]. No effect in adjuvant setting was detected (interaction test $\mathrm{p}=$ 
.20), but only a trend toward a major benefit for high expression [76]. Other analyses were performed to assess the prognostic and predictive value of p-53 and KRAS. While neither P53 IHC expression nor mutation were prognostic for survival, a trend toward a positive predictive role was seen in wild type patients (significant for squamous cell) [77]. Regarding KRAS, a non significant trend toward a worse OS was seen for mutated patients (significant only for non squamous non adenocarcinoma), with predictive role [78].

- Other studies: additional potential biomarkers or classifiers involving different pathways (DNA methylation, mTOR, cytoskeleton protein expression) have been retrospectively evaluated in other studies. Results are promising but should be validated in prospective larger randomized clinical trials [79-82].

\section{The target therapy paradox}

The biomarker-selection approach, i.e. the treatment assignment according to the expression of featured molecular/classifier signatures (for example ERCC1 and BRCA1 for cisplatinum, RRM for gemcitabine) is the basis of many ongoing clinical trials in order to further optimize and customize ACT (table 1).
While target therapy has dramatically changed the treatment of advanced stage NSCLC, its results in resected NSCLC are currently disappointing. Indeed, the JBR-19 trial, designed to evaluate the benefit of Gefitinib regardless of chemotherapy in unselected patients with resected stage IB-IIIA, did not show any benefit over placebo (and prematurely closed on the basis of the negative results of the ISEL [83] and SWOG 0023 trials [84]) [85]. Moreover, although underpowered to draw definitive conclusions (500 patients out of the 1200 planned), even in the EGFR-mutant patient subgroup no difference in favor of Gefitinib was determined. In this trial, both EGFR mutation/amplification and K-RAS status were neither prognostic for OS nor predictive of outcome.

These disappointing data suggest that: 1) the efficacy of the administration of a targeted agents in patients expressing a sensitizing biomarker, may be diluted in the context of an unselected population; 2) the biological background behind advanced and surgically removed disease can be extremely different. In this direction, retrospective analyses, such as the one from the MSKCC, indicate a potential benefit (a trend toward better disease-free survival) of Gefitinib or Erlotinib after adjuvant chemotherapy in EGFR-mutant patients [86]. The results of the ongoing RADIANT trial, randomizing only EGFR positive patients (IHC or

Table 1 Ongoing clinical trials in adjuvant setting

\begin{tabular}{|c|c|c|c|c|}
\hline $\begin{array}{c}\text { Trial/ } \\
\text { Acronym }\end{array}$ & Stage & Marker & Design & Notes \\
\hline RADIANT & $|-||| A$ & EGFR $I H C$ pos & $\begin{array}{l}4 \text { cycles of optional ACT followed by } 2 \text { years of } \\
\text { TKI or placebo }\end{array}$ & $\begin{array}{l}\text { - Phase III, placebo controlled; Erlotinib } 150 \text { mg/die } \\
\times 2 \text { years } \\
\text { • Primary endpoint: DFS }\end{array}$ \\
\hline ECOG 1505 & $\begin{array}{l}\mathrm{IB}(>4 \mathrm{~cm})- \\
\quad \text { IIA }\end{array}$ & None & $\begin{array}{l}\text { Clinician choice ACT vs Clinician choice ACT + } \\
\text { Bevacizumab }\end{array}$ & $\begin{array}{l}\text { - Phase III (2:1); Bevacizumab } 15 \mathrm{mg} / \mathrm{kg} / 3 \text { wks } \\
\text { - Primary endpoint: OS } \\
\text { - Secondary endpoint: DFS, toxicities }\end{array}$ \\
\hline SCAT & I-IIIA & BRCA & CDDP DOC vs "gen assigned CT" & $\begin{array}{l}\text { - Phase III (3:1) CDDP DOC/DOC/CDDP GEM vs } \\
\text { CDDP/DOC } \\
\text { - Primary endpoint: DFS } \\
\text { - Secondary endpoint: OS, toxicities }\end{array}$ \\
\hline TASTE & I-IIIA & $\begin{array}{c}\text { ERCC1/EGFR } \\
\text { mutant }\end{array}$ & CDDP/ERL & - Phase II feasibility \\
\hline SWOG 0720 & I & ERCC1/RRM1 & Follow up or ACT according to risk profile & - Phase II feasibility \\
\hline MAGRIT & $|\mathrm{B}-| \mid \mathrm{A}$ & MAGE A3 + & Vaccine vs placebo after optional ACT & $\begin{array}{l}\text { - Phase III (2:1) placebo controlled; separate } \\
\text { analysis for ACT +/- } \\
\text { - Primary endpoint: DFS } \\
\text { - Secondary endpoint: OS }\end{array}$ \\
\hline ITACA & $\|-I\| A$ & ERCC1/TS & ACT assigned according to markers expression & $\begin{array}{l}\text { - Phase III } \\
\text { - Primary end-point: OS }\end{array}$ \\
\hline TREAT & $|\mathrm{B}-||| \mathrm{A}$ & None & CDDP PEM vs CDDP GEM & $\begin{array}{l}\text { - Randomized phase II } \\
\text { - Primary endpoint: feasibility } \\
\text { - Secondary endpoint: toxicity, delivery }\end{array}$ \\
\hline
\end{tabular}

EGFR: epidermal growth factor receptor; IHC: immunohistochemistry; ACT: adjuvant chemotherapy; TKI: tyrosine kinase inhibitors; DFS: disease-free survival; OS: overall survival; CDDP: cisplatin; DOC: docetaxel; GEM: gemcitabine; ERCC: Excision Repair Cross-Complementation gene; RRM: ribonucleotide reductase M1 gene; MAGE: melanoma-associated antigen; TS: thymidylate synthetase; PEM: pemetrexed. 
FISH) to 2 years of Erlotinib vs placebo after optional $\mathrm{ACT}$, are awaited.

\section{Conclusions}

ACT for radically resected NSCLC is now part of the routine clinical approach to early NSCLC and is certainly contributing to the decrease in mortality observed in these patients in recent years. While many important 'technical' questions, such as optimal treatment for Stage I patients, best platinum based combination, and optimal use of PORT to name a few, remain to be answered to further refine currently achievable results, the biggest challenge ahead is to better understand the underlying biology of the disease and to incorporate biological advances into clinical treatment algorithms. Ongoing adjuvant trials, such as the italian ITACA, will hopefully assess the role of pharmacogenomically 'tailored' ACT to optimize the use of currently available classical cytotoxic agents; however, genetic and epigenetic drivers of early NSCLC must be clearly identified in order to generate a further 'leap' in the management of resectable NSCLC patients, both in terms of accurate prognostication and risk assessment and in terms of better prediction of sensitivity/resistance to specific targeted treatments. The ever growing knowledge on molecular pathways, cancer stem cell populations, and genetic/epigenetic programs regulating the invasive and metastatic phenotype will shed new light on the right path to be undertaken in order to ensure the best treatment to each specific patient population.

\section{Acknowledgements}

This work was supported by grants from the Italian Association for Cancer Research (AIRC), and the Italian Ministry of Health.

\section{Author details}

${ }^{1}$ Medical Oncology, Azienda Ospedaliera Universitaria Integrata (AOUI), Verona, Italy. ${ }^{2}$ Department of Medical Oncology, Regina Elena National Cancer Institute, Roma, Italy. ${ }^{3}$ Pathology, AOUI, Verona, Italy.

\section{Authors' contributions}

All named authors conceived for the study, participated in its design and coordination and helped to draft the manuscript. All authors read and approved the final manuscript.

\section{Competing interests}

The authors declare that they have no competing interests.

Received: 11 November 2011 Accepted: 29 December 2011 Published: 29 December 2011

\section{References}

1. Crino L, Weder W, van Meerbeeck J, Felip E: Early stage and locally advanced (non-metastatic) non-small-cell lung cancer: ESMO Clinical Practice Guidelines for diagnosis, treatment and follow-up. Ann Oncol 21(Suppl 5):v103-115.

2. Pisters KM, Evans WK, Azzoli CG, Kris MG, Smith CA, Desch CE, Somerfield MR, Brouwers MC, Darling G, Ellis PM, et al: Cancer Care Ontario and American Society of Clinical Oncology adjuvant chemotherapy and adjuvant radiation therapy for stages I-IIIA resectable non small-cell lung cancer guideline. J Clin Oncol 2007, 25:5506-5518.

3. [http://www.nccn.org/professionals/physician_gls/pdf/nscl.pdf].

4. Robinson LA, Ruckdeschel JC, Wagner H Jr, Stevens CW: Treatment of nonsmall cell lung cancer-stage IIIA: ACCP evidence-based clinical practice guidelines. Chest , 2 2007, 132:243S-265S.

5. Scott WJ, Howington J, Feigenberg S, Movsas B, Pisters K: Treatment of non-small cell lung cancer stage I and stage II: ACCP evidence-based clinical practice guidelines. Chest , 2 2007, 132:234S-242S.

6. Chemotherapy in non-small cell lung cancer: a meta-analysis using updated data on individual patients from 52 randomised clinical trials. Non-small Cell Lung Cancer Collaborative Group. BMJ 1995, 311:899-909.

7. Douillard JY, Rosell R, De Lena M, Carpagnano F, Ramlau R, GonzalesLarriba JL, Grodzki T, Pereira JR, Le Groumellec A, Lorusso V, et al: Adjuvant vinorelbine plus cisplatin versus observation in patients with completely resected stage IB-IIIA non-small-cell lung cancer (Adjuvant Navelbine International Trialist Association [ANITA]): a randomised controlled trial. Lancet Oncol 2006, 7:719-727.

8. Winton T, Livingston R, Johnson D, Rigas J, Johnston M, Butts C, Cormier Y, Goss $G$, Inculet $R$, Vallieres $E$, et al: Vinorelbine plus cisplatin vs. observation in resected non-small-cell lung cancer. N Engl J Med 2005, 352:2589-2597.

9. Butts CA, Ding K, Seymour L, Twumasi-Ankrah P, Graham B, Gandara D, Johnson DH, Kesler KA, Green M, Vincent M, et al: Randomized phase III trial of vinorelbine plus cisplatin compared with observation in completely resected stage IB and II non-small-cell lung cancer: updated survival analysis of JBR-10. J Clin Oncol 28:29-34.

10. Arriagada R, Bergman B, Dunant A, Le Chevalier T, Pignon JP, Vansteenkiste J: Cisplatin-based adjuvant chemotherapy in patients with completely resected non-small-cell lung cancer. N Engl J Med 2004, 350:351-360.

11. Arriagada R, Dunant A, Pignon JP, Bergman B, Chabowski M, Grunenwald D, Kozlowski M, Le Pechoux C, Pirker R, Pinel MI, et al: Long-term results of the international adjuvant lung cancer trial evaluating adjuvant Cisplatin-based chemotherapy in resected lung cancer. $J$ Clin Oncol 28:35-42.

12. Strauss GM, Herndon J, Maddaus MA, Johnstone DW, Johnson EA, Watson DM, Sugarbaker DJ, Schilsky RL, Green MR: Randomized Clinical Trial of adjuvant chemotherapy with paclitaxel and carboplatin following resection in Stage IB Non-Small Cell Lung Cancer (NSCLC): Report of Cancer and Leukemia Group B (CALGB) Protocol 9633. ASCO Meeting Abstracts 2004, 22:7019.

13. Strauss GM, Herndon JE, Maddaus MA, Johnstone DW, Johnson EA, Harpole DH, Gillenwater HH, Watson DM, Sugarbaker DJ, Schilsky RL, et al: Adjuvant paclitaxel plus carboplatin compared with observation in stage IB non-small-cell lung cancer: CALGB 9633 with the Cancer and Leukemia Group B, Radiation Therapy Oncology Group, and North Central Cancer Treatment Group Study Groups. J Clin Oncol 2008, 26:5043-5051.

14. Waller D, Peake MD, Stephens RJ, Gower NH, Milroy R, Parmar MK, Rudd RM, Spiro SG: Chemotherapy for patients with non-small cell lung cancer: the surgical setting of the Big Lung Trial. Eur J Cardiothorac Surg 2004, 26:173-182.

15. Scagliotti GV, Fossati R, Torri V, Crino L, Giaccone G, Silvano G, Martelli M, Clerici M, Cognetti F, Tonato M: Randomized study of adjuvant chemotherapy for completely resected stage I, II, or IIIA non-small-cell Lung cancer. J Natl Cancer Inst 2003, 95:1453-1461.

16. Keller SM, Adak S, Wagner H, Herskovic A, Komaki R, Brooks BJ, Perry MC, Livingston RB, Johnson DH: A randomized trial of postoperative adjuvant therapy in patients with completely resected stage II or IIIA non-smallcell lung cancer. Eastern Cooperative Oncology Group. N Engl J Med 2000, 343:1217-1222.

17. Douillard JY: Adjuvant chemotherapy for non-small-cell lung cancer: it does not always fade with time. J Clin Oncol 28:3-5.

18. Pignon JP, Tribodet H, Scagliotti GV, Douillard JY, Shepherd FA, Stephens RJ, Dunant A, Torri V, Rosell R, Seymour L, et al: Lung adjuvant cisplatin evaluation: a pooled analysis by the LACE Collaborative Group. J Clin Oncol 2008, 26:3552-3559.

19. Berghmans T, Paesmans M, Meert AP, Mascaux C, Lothaire P, Lafitte JJ, Sculier JP: Survival improvement in resectable non-small cell lung cancer 
with (neo)adjuvant chemotherapy: results of a meta-analysis of the literature. Lung Cancer 2005, 49:13-23.

20. Bria E, Gralla RJ, Raftopoulos H, Cuppone F, Milella M, Sperduti I, Carlini P, Terzoli E, Cognetti F, Giannarelli D: Magnitude of benefit of adjuvant chemotherapy for non-small cell lung cancer: meta-analysis of randomized clinical trials. Lung Cancer 2009, 63:50-57.

21. Hotta K, Matsuo K, Ueoka H, Kiura K, Tabata M, Tanimoto M: Role of adjuvant chemotherapy in patients with resected non-small-cell lung cancer: reappraisal with a meta-analysis of randomized controlled trials. J Clin Oncol 2004, 22:3860-3867.

22. Sedrakyan A, Van Der Meulen J, O'Byrne K, Prendiville J, Hill J, Treasure T: Postoperative chemotherapy for non-small cell lung cancer: A systematic review and meta-analysis. J Thorac Cardiovasc Surg 2004, 128:414-419.

23. Arriagada R, Auperin A, Burdett S, Higgins JP, Johnson DH, Le Chevalier T, Le Pechoux C, Parmar MK, Pignon JP, Souhami RL, et al: Adjuvant chemotherapy, with or without postoperative radiotherapy, in operable non-small-cell lung cancer: two meta-analyses of individual patient data. Lancet 2010, 375:1267-1277.

24. Banna GL, Di Maio M, Follador A, Collova E, Menis J, Novello S, Bria E, Airoldi M, Amoroso D, Ardizzoia A, et al: Italian Survey on adjuvant treatment of non-small cell lung cancer (ISA). Lung Cancer 73:78-88.

25. Booth CM, Shepherd FA, Peng Y, Darling GE, Li G, Kong W, Mackillop WJ: Adoption of adjuvant chemotherapy for non-small-cell lung cancer: a population-based outcomes study. J Clin Oncol 28:3472-3478.

26. Cuffe S, Booth CM, Peng Y, Darling GE, Li G, Kong W, Mackillop WJ, Shepherd FA: Adoption of adjuvant chemotherapy (ACT) for non-small cell lung cancer (NSCLC) in the elderly: A population-based outcomes study. ASCO Meeting Abstracts 29:7012.

27. Gu F, Strauss GM, Wisnivesky JP: Platinum-based adjuvant chemotherapy (ACT) in elderly patients with non-small cell lung cancer (NSCLC) in the SEER-Medicare database: Comparison between carboplatin- and cisplatin-based regimens. ASCO Meeting Abstracts 29:7014.

28. Wisnivesky JP, Smith CB, Packer S, Strauss GM, Lurslurchachai L, Federman A, Halm EA: Survival and risk of adverse events in older patients receiving postoperative adjuvant chemotherapy for resected stages II-IIIA lung cancer: observational cohort study. BMJ 343:d4013.

29. Zornosa C, Mamet R, Reid ME, Ettinger DS, Otterson GA, Rabin MS, Hayman J, Niland JC, Pisters K, Committee NOODN-SCLCD-SE: Utilization of adjuvant therapy among completely resected non-small cell lung cancer (NSCLC) patients in the National Comprehensive Cancer Network (NCCN) Outcomes Database Project. ASCO Meeting Abstracts 28:7017.

30. Miksad RA, Gonen M, Lynch TJ, Roberts TG Jr: Interpreting trial results in light of conflicting evidence: a Bayesian analysis of adjuvant chemotherapy for non-small-cell lung cancer. J Clin Oncol 2009, 27:2245-2252.

31. Strauss GM, Wang XF, Maddaus M, Johnstone D, Johnson E, Harpole D, Gillenwater HH, Gu L, Sugarbaker D, Green MR, et al: Adjuvant chemotherapy (AC) in stage IB non-small cell lung cancer (NSCLC): Long-term follow-up of Cancer and Leukemia Group B (CALGB) 9633. ASCO Meeting Abstracts 29:7015.

32. Kato $H$, Ichinose $Y$, Ohta M, Hata E, Tsubota $N$, Tada H, Watanabe $Y$, Wada $H$, Tsuboi M, Hamajima N: A randomized trial of adjuvant chemotherapy with uracil-tegafur for adenocarcinoma of the lung. $N$ Engl J Med 2004, 350:1713-1721.

33. Wakelee H, Dubey S, Gandara D: Optimal adjuvant therapy for non-small cell lung cancer-how to handle stage I disease. Oncologist 2007, 12:331-337.

34. Rami-Porta R, Ball D, Crowley J, Giroux DJ, Jett J, Travis WD, Tsuboi M, Vallieres E, Goldstraw P: The IASLC Lung Cancer Staging Project: proposals for the revision of the T descriptors in the forthcoming (seventh) edition of the TNM classification for lung cancer. J Thorac Oncol 2007, 2:593-602.

35. Goldstraw P, Crowley J, Chansky K, Giroux DJ, Groome PA, Rami-Porta R, Postmus PE, Rusch V, Sobin L: The IASLC Lung Cancer Staging Project: proposals for the revision of the TNM stage groupings in the forthcoming (seventh) edition of the TNM Classification of malignant tumours. J Thorac Oncol 2007, 2:706-714.

36. Ruffini E, Asioli S, Filosso PL, Buffoni L, Bruna MC, Mossetti C, Solidoro P. Oliaro A: Significance of the presence of microscopic vascular invasion after complete resection of Stage I-II PT1-T2NO non-small cell lung cancer and its relation with T-Size categories: did the 2009 7th edition of the TNM staging system miss something? J Thorac Oncol 6:319-326.

37. Maeda R, Yoshida J, Ishii G, Hishida T, Nishimura M, Nagai K: Poor prognostic factors in patients with stage IB non-small cell lung cancer according to the seventh edition TNM classification. Chest 139:855-861.

38. Postoperative radiotherapy in non-small-cell lung cancer: systematic review and meta-analysis of individual patient data from nine randomised controlled trials. PORT Meta-analysis Trialists Group. Lancet 1998, 352:257-263.

39. Postoperative radiotherapy for non-small cell lung cancer. Cochrane Database Syst Rev 2005, CD002142.

40. Munro AJ: What now for postoperative radiotherapy for lung cancer? Lancet 1998, 352:250-251.

41. Douillard JY, Rosell R, De Lena M, Riggi M, Hurteloup P, Mahe MA: Impact of postoperative radiation therapy on survival in patients with complete resection and stage I, II, or IIIA non-small-cell lung cancer treated with adjuvant chemotherapy: the adjuvant Navelbine International Trialist Association (ANITA) Randomized Trial. Int J Radiat Oncol Biol Phys 2008, 72:695-701.

42. Lally BE, Detterbeck FC, Geiger AM, Thomas CR Jr, Machtay M, Miller AA, Wilson LD, Oaks TE, Petty WJ, Robbins ME, Blackstock AW: The risk of death from heart disease in patients with nonsmall cell lung cancer who receive postoperative radiotherapy: analysis of the Surveillance, Epidemiology, and End Results database. Cancer 2007, 110:911-917.

43. Matsuguma H, Nakahara R, Ishikawa Y, Suzuki H, Inoue K, Katano S, Yokoi K: Postoperative radiotherapy for patients with completely resected pathological stage IIIA-N2 non-small cell lung cancer: focusing on an effect of the number of mediastinal lymph node stations involved. Interact Cardiovasc Thorac Surg 2008, 7:573-577.

44. Sawyer TE, Bonner JA, Gould PM, Foote RL, Deschamps C, Trastek VF, Pairolero PC, Allen MS, Lange CM, Li H: Effectiveness of postoperative irradiation in stage IIIA non-small cell lung cancer according to regression tree analyses of recurrence risks. Ann Thorac Surg 1997, 64:1402-1407, discussion 1407-1408.

45. Pepe C, Hasan B, Winton TL, Seymour L, Graham B, Livingston RB, Johnson DH, Rigas JR, Ding K, Shepherd FA: Adjuvant vinorelbine and cisplatin in elderly patients: National Cancer Institute of Canada and Intergroup Study JBR.10. J Clin Oncol 2007, 25:1553-1561.

46. Fruh $M$, Rolland E, Pignon JP, Seymour L, Ding K, Tribodet $H$, Winton $T$, Le Chevalier T, Scagliotti GV, Douillard JY, et al: Pooled analysis of the effect of age on adjuvant cisplatin-based chemotherapy for completely resected non-small-cell lung cancer. J Clin Oncol 2008, 26:3573-3581.

47. Fervers B: Chemotherapy in elderly patients with resected stage II-IIIA lung cancer. BMJ 343:d4104.

48. Alam N, Shepherd FA, Winton T, Graham B, Johnson D, Livingston R, Rigas J, Whitehead M, Ding K, Seymour L: Compliance with post-operative adjuvant chemotherapy in non-small cell lung cancer. An analysis of National Cancer Institute of Canada and intergroup trial JBR.10 and a review of the literature. Lung Cancer 2005, 47:385-394.

49. Strauss GM, Herndon JE, Maddaus MA, Johnstone DW, Johnson EA, Watson DM, Sugarbaker DJ, Schilsky RA, Vokes EE, Green MR, The Calgb RTOG: Adjuvant chemotherapy in stage IB non-small cell lung cancer (NSCLC): Update of Cancer and Leukemia Group B (CALGB) protocol 9633. ASCO Meeting Abstracts 2006, 24:7007.

50. Besse B, Le Chevalier T: Adjuvant chemotherapy for non-small-cell lung cancer: a fading effect? J Clin Oncol 2008, 26:5014-5017.

51. Custodio AB, Gonzalez-Larriba JL, Bobokova J, Calles A, Alvarez R, Cuadrado E, Manzano A, Diaz-Rubio E: Prognostic and predictive markers of benefit from adjuvant chemotherapy in early-stage non-small cell lung cancer. J Thorac Oncol 2009, 4:891-910.

52. Xie Y, Minna JD: Non-small-cell lung cancer mRNA expression signature predicting response to adjuvant chemotherapy. I Clin Oncol 28:4404-4407.

53. Sculier JP, Chansky K, Crowley JJ, Van Meerbeeck J, Goldstraw P: The impact of additional prognostic factors on survival and their relationship with the anatomical extent of disease expressed by the 6th Edition of the TNM Classification of Malignant Tumors and the proposals for the 7th Edition. J Thorac Oncol 2008, 3:457-466.

54. Bria E, Milella M, Sperduti I, Alessandrini G, Visca P, Corzani F, Giannarelli D, Cerasoli V, Cuppone F, Cecere FL, et al: A novel clinical prognostic score incorporating the number of resected lymph-nodes to predict 
recurrence and survival in non-small-cell lung cancer. Lung Cancer 2009, 66:365-371.

55. Jonnalagadda S, Arcinega J, Smith C, Wisnivesky JP: Validation of the lymph node ratio as a prognostic factor in patients with $\mathrm{N} 1$ nonsmall cell lung cancer. Cancer.

56. Jonnalagadda S, Smith C, Mhango G, Wisnivesky JP: The Number of Lymph Node Metastases as a Prognostic Factor in Patients With N1 Non-small Cell Lung Cancer. Chest 140:433-440.

57. Chen HY, Yu SL, Chen $\mathrm{CH}$, Chang GC, Chen $\mathrm{CY}$, Yuan $\mathrm{A}$, Cheng $\mathrm{CL}$, Wang $\mathrm{CH}$, Terng $\mathrm{HJ}$, Kao SF, et al: A five-gene signature and clinical outcome in non-small-cell lung cancer. N Engl J Med 2007, 356:11-20.

58. Kadara H, Behrens C, Yuan P, Solis L, Liu D, Gu X, Minna JD, Lee JJ, Kim E, Hong WK, et al: A five-gene and corresponding protein signature for stage-l lung adenocarcinoma prognosis. Clin Cancer Res 17:1490-1501.

59. Patnaik SK, Kannisto E, Knudsen S, Yendamuri S: Evaluation of microRNA expression profiles that may predict recurrence of localized stage I nonsmall cell lung cancer after surgical resection. Cancer Res 70:36-45.

60. Potti A, Mukherjee S, Petersen R, Dressman HK, Bild A, Koontz J, Kratzke R, Watson MA, Kelley M, Ginsburg GS, et al: A genomic strategy to refine prognosis in early-stage non-small-cell lung cancer. N Engl J Med 2006, 355:570-580

61. Skrzypski M, Jassem E, Taron M, Sanchez JJ, Mendez P, Rzyman W, Gulida G, Raz D, Jablons D, Provencio M, et al: Three-gene expression signature predicts survival in early-stage squamous cell carcinoma of the lung. Clin Cancer Res 2008, 14:4794-4799.

62. Yanagisawa K, Tomida S, Shimada Y, Yatabe Y, Mitsudomi T, Takahashi T: A 25-signal proteomic signature and outcome for patients with resected non-small-cell lung cancer. J Natl Cancer Inst 2007, 99:858-867.

63. Konopa K: Do we have markers to select patients for adjuvant therapies of non-small-cell lung cancer? Ann Oncol 21(Suppl 7):vii199-202.

64. Shedden K, Taylor JM, Enkemann SA, Tsao MS, Yeatman TJ, Gerald WL, Eschrich S, Jurisica I, Giordano TJ, Misek DE, et al: Gene expression-based survival prediction in lung adenocarcinoma: a multi-site, blinded validation study. Nat Med 2008, 14:822-827.

65. Subramanian J, Simon R: Gene expression-based prognostic signatures in lung cancer: ready for clinical use? J Natl Cancer Inst 102:464-474.

66. Potti A, Mukherjee S, Petersen R, Dressman HK, Bild A, Koontz J, Kratzke R, Watson MA, Kelley M, Ginsburg GS, et al: Retraction: A genomic strategy to refine prognosis in early-stage non-small-cell lung cancer. $N$ Engl J Med 2006;355:570-80. N Engl J Med 364:1176.

67. Pao W, Chmielecki J: Rational, biologically based treatment of EGFRmutant non-small-cell lung cancer. Nat Rev Cancer 10:760-774.

68. Olaussen KA, Dunant A, Fouret P, Brambilla E, Andre F, Haddad V, Taranchon E, Filipits M, Pirker R, Popper HH, et al: DNA repair by ERCC1 in non-small-cell lung cancer and cisplatin-based adjuvant chemotherapy. N Engl J Med 2006, 355:983-991.

69. Filipits M, Pirker R, Dunant A, Lantuejoul S, Schmid K, Huynh A, Haddad V, Andre F, Stahel R, Pignon JP, et al: Cell cycle regulators and outcome of adjuvant cisplatin-based chemotherapy in completely resected nonsmall-cell lung cancer: the International Adjuvant Lung Cancer Trial Biologic Program. J Clin Oncol 2007, 25:2735-2740.

70. Kamal NS, Soria JC, Mendiboure J, Planchard D, Olaussen KA, Rousseau V, Popper H, Pirker R, Bertrand P, Dunant A, et al: MutS homologue 2 and the long-term benefit of adjuvant chemotherapy in lung cancer. Clin Cancer Res 16:1206-1215.

71. Filipits M, Haddad V, Schmid K, Huynh A, Dunant A, Andre F, Brambilla E, Stahel R, Pignon JP, Soria JC, et al: Multidrug resistance proteins do not predict benefit of adjuvant chemotherapy in patients with completely resected non-small cell lung cancer: International Adjuvant Lung Cancer Trial Biologic Program. Clin Cancer Res 2007, 13:3892-3898.

72. Voortman J, Goto A, Mendiboure J, Sohn JJ, Schetter AJ, Saito M, Dunant A, Pham TC, Petrini I, Lee A, et al: MicroRNA expression and clinical outcomes in patients treated with adjuvant chemotherapy after complete resection of non-small cell lung carcinoma. Cancer Res 70:8288-8298.

73. Tsao MS, Aviel-Ronen S, Ding K, Lau D, Liu N, Sakurada A, Whitehead M, Zhu CQ, Livingston R, Johnson DH, et al: Prognostic and predictive importance of p53 and RAS for adjuvant chemotherapy in non smallcell lung cancer. J Clin Oncol 2007, 25:5240-5247.

74. Zhu CQ, Ding K, Strumpf D, Weir BA, Meyerson M, Pennell N, Thomas RK, Naoki K, Ladd-Acosta C, Liu N, et al: Prognostic and predictive gene signature for adjuvant chemotherapy in resected non-small-cell lung cancer. J Clin Oncol 28:4417-4424.

75. Seve P, Mackey J, Isaac S, Tredan O, Souquet PJ, Perol M, Lai R, Voloch A, Dumontet C: Class III beta-tubulin expression in tumor cells predicts response and outcome in patients with non-small cell lung cancer receiving paclitaxel. Mol Cancer Ther 2005, 4:2001-2007.

76. Seve P, Lai R, Ding K, Winton T, Butts C, Mackey J, Dumontet C, Dabbagh L, Aviel-Ronen S, Seymour L, et al: Class III beta-tubulin expression and benefit from adjuvant cisplatin/vinorelbine chemotherapy in operable non-small cell lung cancer: analysis of NCIC JBR.10. Clin Cancer Res 2007, 13:994-999.

77. Graziano SL, Paris E, Ma X, Pignon J, Hainaut P, Taron M, Tsao MS, Kratzke R, Brambilla E, Soria JC: LACE-BIO pooled analysis of the prognostic and predictive value of $\mathrm{p} 53$ mutations and expression by immunoistochemistry $(\mathrm{IHC})$ in patients with resected non-small cell lung cancer (NSCLC)- Abs 389P. ESMO Meeting Abstracts 2010, 21.

78. Tsao MS, Hainaut P, Bourredjem A, Janne PA, Pignon J, Douillard J, Soria JC, Seymour L, Shepherd F: LACE-BIO pooled analysis of the prognostic and predictive value of KRAS mutation in completely resected non small cell lung cancer (NSCLC). Abs 1560. ESMO Meeting Abstracts 2010, 21.

79. Zheng Z, Chen T, Li X, Haura E, Sharma A, Bepler G: DNA synthesis and repair genes RRM1 and ERCC1 in lung cancer. N Engl J Med 2007, 356:800-808.

80. Rosell R, Skrzypski M, Jassem E, Taron M, Bartolucci R, Sanchez JJ, Mendez P, Chaib I, Perez-Roca L, Szymanowska A, et al: BRCA1: a novel prognostic factor in resected non-small-cell lung cancer. PLOS One 2007, 2:e1129.

81. Bria E, Mottolese M, Sperduti I, Visca P, Antoniani B, Facciolo F, Di Modugno F, Cognetti F, Nistico P, Milella M: Prognostic impact of the cytoskeleton regulatory protein hMena in resected node-negative nonsmall cell lung cancer (NSCLC): A clinical-biological risk stratification model. ASCO Meeting Abstracts 28:7027.

82. D'Angelo SP, Janjigian YY, Kris MG, Pao W, Riely GJ, Marks J, Sima C, Dycoco J, Park BJ, Azzoli CG: Impact of EGFR and KRAS mutations on survival in 1,000 patients with resected lung adenocarcinoma. ASCO Meeting Abstracts 28:7011.

83. Thatcher N, Chang A, Parikh P, Rodrigues Pereira J, Ciuleanu T, von Pawel J, Thongprasert S, Tan EH, Pemberton K, Archer V, Carroll K: Gefitinib plus best supportive care in previously treated patients with refractory advanced non-small-cell lung cancer: results from a randomised, placebo-controlled, multicentre study (Iressa Survival Evaluation in Lung Cancer). Lancet 2005, 366:1527-1537.

84. Kelly K, Chansky K, Gaspar LE, Albain KS, Jett J, Ung YC, Lau DH, Crowley JJ, Gandara DR: Phase III trial of maintenance gefitinib or placebo after concurrent chemoradiotherapy and docetaxel consolidation in inoperable stage III non-small-cell lung cancer: SWOG S0023. J Clin Oncol 2008, 26:2450-2456.

85. Goss GD, Lorimer I, Tsao MS, O'Callaghan CJ, Ding K, Masters GA, Roberts P, Jett JR, Edelman MJ, Shepherd FA: A phase III randomized, double-blind, placebo-controlled trial of the epidermal growth factor receptor inhibitor gefitinb in completely resected stage IB-IIIA non-small cell lung cancer (NSCLC): NCIC CTG BR.19. ASCO Meeting Abstracts 28:LBA7005.

86. Janjigian YY, Park BJ, Zakowski MF, Ladanyi M, Pao W, D'Angelo SP, Kris MG Shen R, Zheng J, Azzoli CG: Impact on disease-free survival of adjuvant erlotinib or gefitinib in patients with resected lung adenocarcinomas that harbor EGFR mutations. J Thorac Oncol 6:569-575.

doi:10.1186/1756-9966-30-115

Cite this article as: Bonomi et al:: Adjuvant chemotherapy for resected non-small-cell lung cancer: future perspectives for clinical research. Journal of Experimental \& Clinical Cancer Research 2011 30:115. 